\title{
ANALISIS KETAHANAN PANGAN MELALUI PEMODELAN USAHA TANI SINGKONG
}

\author{
Masyhuri Machfudz \\ Nikmatul Khoiriyah \\ Universitas Islam Malang (Unisma) \\ Jalan MT. Haryono 193 Malang \\ Email: masyhuri_machfudz@yahoo.com
}

Amway.2764770@gmail.com

\begin{abstract}
: aim this research are i) description analyze of cassava distribution optimalisize and useful analyze 'berusahatani' of cassava at Malang regency. The Method by using qualitative description approach. The research result shows that: (i) Malang Regency unreach optimally result because of unbalance. It means still occur over and less of production supply and demand of cassava. (ii) empowering farmer family, by using clear area which get social, economic, healthy and culture advantage. Planting cassava in the clear area rises awareness that using land area well will avoid of useless activity. Beside of that by using clear land can minimalize plant desease cause of rat. According the local society, by that way the rat will feel happy and comforted ('keslimur': javanese). These result of research can be recommended that culture of planting cassava is so significant to support of food guard in this country.
\end{abstract}

Keywords: singkong, pemanfaatan lahan kosong dan ketahanan pangan

Singkong, yang juga dikenal sebagai ketela pohon atau ubi kayu, adalah pohon tahunan tropika dan subtropika dari keluarga Euphorbiaceae. Umbinya dikenal luas sebagai makanan pokok penghasil karbohidrat dan daunnya sebagai sayuran. Produksi dunia sebesar 232.950.180 ton, terbanyak di Nigeria 44.582 .000 ton dan di Indonesia sebanyak 21.593.052 ton. Sejalan dengan berkurangnya lahan pertanian ke sektor perumahan, maka singkongpun produksinya semakin turun. Penuruanan ini diestimasikan dari tahun ke tahun semakin melaju sehingga perlu penanganan/alternatif upaya lain dalam mengatasi kekurangan lahan untuk singkong dan/atau kekurangan bahan baku makanan berbasis singkong

Salah satu upaya ini adalah pemanfaatan lahan-lahan kosong/pematang seefektif dan efisien mungkin sebab perilaku petani (kecil) dalam berusahatani Orientasinya hanya untuk memenuhi kebutuhan dirinya sendiri dan keluarganya 
(subsisten) dengan komoditas padi dan luas lahan yang dimiliki kurang dari 0,5 hektar. Hal ini menyebabkan kebutuhan pokok rumah tangga tani di bawah kecukupan, untuk menutupinya dipakai sebagai alternatif bahan kebutuhan pangan adalah komoditas singkong.

Singkong dapat diusahakan pada lahan tegal dan pekarangan mengingat komoditas ini tidak membutuhkan air sebagaimana tanaman padi atau sayur-sayuran. Keadaan ini menyebabkan usahatani singkong sering dilakukan oleh petani dengan orientasi pada usaha samping dan pola usahatani sampingan. Kesan yang cukup mendalam pada perilaku petani produsen singkong adalah kurang optimal, hal ini diindikasikan dengan pemanfaatan sumberdaya lahan (SDL) untuk singkong masing katagori sampingan. Kenyataan ini didukung dengan kondisi lahan pertanian (sawah) di Kabupaten Malang mengalami penurunan 25\% untuk kepentingan industri perumahan dalam waktu 5 tahun terakhir ini.

Penelitian ini dilakukan dengan melakukan pemberdayaan rumah tangga tani sebagai melalui pemanfaatan lahan kosong dan/pekarang guna menghindari kemubadiran lahan. Kajian kemubadziran ini dilakukan sebagai upaya mensinegikan antara science dan ilmu agama. Demikian juga akan dilakukan analisis kaitan pemanfaatan lahan kosong dengan aspek agama khususnya kemubadziran. Komunitas akan merasa kemanfaatannya karena selama ini lahan galengan, pekarangan dan lahan kosong tidak dipergunakan untuk 'apa-apa' dibiarkan dalam begitu saja. Hal inilah yang diimplikasikan sebagai lahan yang 'mubadhir' - pahaal jika dimanfaatkan akan mendatangkan hasil (product).

Alasan memilih petani kecil (tani) karena kehidupan masyarakat tani cenderung apriori dan menerima terhadap nasib, dan lemah dalam berinovasi sering menimbulkan efek-efek yang negatif dalam berusatani di masyarakat. Mata pencaharian mereka selain tani adalah bekerja secara serabutan, buruh tani, ternak sapi/kambing, ayam dan lain sebagainya tidak bisa dijadikan penopang kehidupan dirinya maupun keluarganya. Kondisi ini, ditambah dengan perilaku usahatani terkesan 'apa adanya' dan kreatiivtas usahatani kurang dikembangkan, banyak tanah 'kosong' yang dapat dimanfaatkan untuk komoditas selain padi seperti singkong. Namun mereka tidak melakukannya sehingga secara ekonomi semakin menjepit kondisi mereka. 
Banyak di antara mereka yang ingin lepas kendali dari ketertindasan ekonomi tersebut. Indikasinya usaha sampingan dilakukan dengan penanaman pisang, jagung pada pematang lahan dan lainnya, tetapi ada kendala pasar yang masih kurang mendukung. Lemahnya pilihan (choice) komoditas ini mempunyai dampak terhadap eksistensi maisyah mereka, untuk mengatasi ini dengan jalan melalui intensifikasi model usahatani dengan pendampingan.

Kondisi desa ini secara kelembagaan cukup kuat karena masyarakat yang bersifat agamis seperti tahlilan, yasinan, serta perkumpulan remaja atau anak muda yang bersifat baik, mendorong kami sebagai civitas akademika Unisma Malang untuk merasa ikut bertanggung jawab untuk membenahi kondisi masyarakat tersebut dan berusaha menciptakan usahatani dengan konsep efektifitas dan efesiensi sehingga terhindar dari kemubadziran. Kelembagaan terbangun secara alami dan/atau tanpa disadari adalah seringnya kelompok sasaran melakukan jamaah sholat tiap waktu sehingga silaturrahim terbangun secara kontinyu dan kuat didalamnya.

Atas dasar uraian diatas ada beberapa alasan mendasar, yaitu kelembagaan telah terbentuk, letak geografis cukup strategis. Namun daerah ini, khususnya lahan pertanian irigasi teknis yang menjadi sasaran pengembangan industri perumahan sehingga banyak tanah 'menganggur/kosong' akibat dari menunggu giliran pelaksanaan pembangunan. Alasan lain mendorong pelaksanaan penelitian adalah kondisi mata pencaharian masyarakat $95 \%$ adalah petani yang diestimasikan akan membantu kemudahan dalam melaksanakan program.

Ide dasar usahatani singkong dengan pemanfaatan lahan seoptimal mungkin ini sebagai upaya untuk membatu kelompok sasaran dengan kesepakatan (agreement) bersama tanpa ada paksaan. Kebersamaan dalam penelitian ini yang lebih diutama khsususnya dalam mengambil keputusan, apalagi menyangkut kebutuhan pokok mereka. Hasil penelitian akan dianalisis dari berbagai aspek before and after sebab dorongan mengangkat komoditas singkong ini sebaga upaya untuk menuju ketahanan pangan diperlukan keberanian mengubah pola konsumsi dan melakukan diversifikasi pangan. Potensi ketersediaan singkong yang melimpah di bumi nusantara ini bisa menjadi alternatif andalan untuk mewujudkan ketahanan pangan dan surplus beras sebesar 10 juta ton pada tahun 2014 yang akan datang. 
Meskipun kondisi dampingan telah terbiasa dalam melaksanakan usahatani tetapi dalam implemetasi program inovasi ini perlu melakukan kesepakatan (agreement) secara hati-hati. Untuk itu signifikansi dalam proses pemberdayaannya adalah melalui 3 (tiga) alasan mendasar yang disebutkan dimuka akan dipakai sebagai dasar untuk menyakinkan dalam pelaksanaan kesepakatan, yaitu: Pertama, terdapatnya kemitraan antara produsen dan distributor singkong sebagai pelaku pasar produksi. Kedua, Ilmu pengetahuan dan teknologi (Iptek) pemanfaatan lahan kosong/pekarangan/pematang dengan usahatani singkong adalah bukan kebutuhan peneliti LPPM Unisma, tetapi kebutuhan mereka (kelompok sasaran) (no need researcher but need society), dan ketiga, Iptek yang diadopsikan dengan usahatani singkong tidak akan MENGALAHKAN keberadaan (eksistensi) yang selama ini mereka miliki.

Atas dasar itulah, maka penelitian ini akan menganalisis beberapa hal, diantaranya adalah: 1) Analisis jalinan kemitraan before and after program penelitian tindakan ini antara produsen dan distributor singkong. 2) Analisis pemanfaatan lahan kosong kelebihan dan kekurangannya secara sosial ekonomi. 3) Analisis pemanfaatan keberadaan (eksistensi) secara mendalam atas adopsi usatanai singkong dengan pemodelan di atas.

\section{Kajian Pustaka}

Masyarakat tani di lokasi dampingan kurangnya perhatian keluarga terhadap pemanfaatan lahan kosong karena terlalu 'dininabobokkan' dengan data statistis bahwa semua kabupaten di wilayah kerja Jawa Timur adalah penghasil singkong. Secara geografis dua desa tersebut terdesak oleh perluasan perkotaan yang dibarengi dengan perluasan industri perumahan, hampir $44 \%$ petani tidak mempunyai lahan pertanian. Bahkan mirisnya lagi lahan pertanian yang mulannya sebagai sumber maisyah turut terjual, yang pada akhirnya mereka menjadi buruh tani pada 'mantan' lahannya sendiri. Dari situlah cenderung petani melakukan perlakuan usahataninya yang tidak sesuai dengan yang diharapkannya. Namun demikian masih ada peluang dan harapan untuk memberdayakan 'sumber' maisyahnya melalui pemberdayaan pada petani-petani kecil yang lahan pertaniannya masih pada genggamannya dengan jalan intensifikasi (product differsification). 
Problem sosial ketenagakerjaan terjadi bahwa sebagian anak masyarakat tani atau remaja tidak mau bekerja sebagai petani, lebih memilih bekerja pada sektor non pertanian menskipun dengan ketrampilan yang minim dan bahkan tidak jarang mereka tidak dapat di terima bekerja di lembaga, instansi, dan pabrik-pabrik sehingga mereka menjadi remaja pengangguran, pada satu sisi. Di sisi lain pekerja di sektor pertanian semakin berkurang sehingga terdapat keluarga yang karena tidak diberi uang saku cenderung untuk mendapatkannya dengan melakukan tindak kriminalitas. Bukan rahasia lagi, mereka mempunyai persepsi bahwa pertanian adalah sektor tradisional yang identik dengan kemiskinan dan pedesaan - padahal kenyataan tidaklah demikian jika pertanian disikapi dengan optimalisi dalam manajemennya.

Di samping problem sosial yang terjadi di kelompok sasaran, terdapat pula potensi masyarakat yang positif dan dapat dikembangkan antara lain, kegiatan sosial keagamaan seperti tahlil, yasinan, jama'ah sholat rowatib baik di musholla-musholla atau masjid-masjid juga jamaah shalawat nabi, dan sebagainya mereka sangat antusia dan aktif berpartisipasi sekalipun mereka tidak mengamalkan ibadah dengan baik bersifat insidental, belum banyak diintegrasikan nilai-nilai keagamaan. Integrasi nilainilai agama dapat diinjekkan melalui aktivitas pertanian dengan pemanfaat lahan pertanian yang mereka miliki dengan ukuran optimalisasi melalaui pemberdayaan singkong baik pada aspek distribusi maupun usahataninya.

Atas dasar keadaan di atas, maka dapat diimplikasikan bahwa:

Pertama, distribusi singkong dapat dilakukan secara optimal dengan ukuran transportasi dari wilayah yang lebih ke wilayah yang kurang. Hal ini dilakukan sebagai dasar untuk melakukan aksi (action) sebagai kaji tindak pada kelompok sasaran petani kecil (jamaah masjid) melalui bisnis usahatani komoditas singkong guna memenuhi kekurangan permintaan (exes demand) secara regional.

Kedua, kekurangan singkong sebagai bahan baku makanan olahan dapat dilakukan dengan usahatani yang efisien dan efektif sekaligus akan memunculkan efek 'domino' yang cukup luas, salah satunya pemanfaat peluang usahatani dengan pemanfaatan 'lahan kosnong' dan/atau pekarangan. Dan ketiga, kelompok sasaran rata-rata memiliki lahan pertanian yang sempit dan mempunyai lahan pekarangan yang kurang dimanfaatkan. 
Tingkat regional sangat jelas kekurangan dan kelebihan cukup variatif, pada level kabupaten Malang cukup 'unik' perlu dianalisis karena dua lokasi kelompok sasaran tahun sebelumnya keluhan bahwa bahan baku singkong mentah sulit didapat padahal data menunjukkan kelebihan kelebihan. Karena kabupaten Malang pada program insus singkong ditanam pada lahan sawah seluas 11.692 hektar dan tanah kering seluas 33.242 hektar yang tersebar pada 35 kecamatan dan di lokasi penelitian singkong hanya 5 hektar. Kenyataan inilah menyebabkan pelaku ekonomi kreatif (gorengan) kesulitan memperoleh bahan baku singkong.

Dilihat dari mata pencaharian di Desa Ngenep petani sebanyak 3.911 jiwa, maka oleh karena itu sasaran utama dalam aksi (action) program ini terfokus di desa Ngenep dengan jumlah penduduk 13.449 jiwa dan dengan $6.740(50,1 \%)$ laki-laki dan $6.709(49,9 \%)$ perempuan yang mayoraitas beragama Islam sebanyak 13.299 jiwa 98,9 \% sisanya 50 jiwa $(0,37 \%)$ non muslim. Dengan satu akidah yang sama ini, maka aktivitas mudah untuk diijeksikan - apalagi pusat aktivitas selalu barometernya adalah masjid. Kondisi spesifik komunitas yang menjadi fokus dampingan cukup mohogen ini memudah program dijalankan.

\section{METODE}

Dalam rangka mengubah kondisi masyarakat tani yang akan melakukan usahatani singkong dengan minimisasi ketidak efisienan lahan digunakan metode PAR (Participatory Action Research). Metode ini dilakukan untuk memahamkan masyarakat tani terhadap: a) kekurangan dan kelemahan masyarakat tani pada akses ekonomi/usahatani, b) keinginan-keinginan masyarakat untuk mengatasi kekurangan dan kelemahan usahataninya, c) menyusun strategi dan metode untuk memecahkan permasalahannya dan d) membantu masyarakat mengatasi, memecahkan, dan menemukan jalan keluarnya.

Metode action ini digunakan memposisikan masyarakat tani (dampingan) sebagai subyek untuk memahami, menginginkan, dan memecahkan permasalahan yang melilitnya sendiri. Kami sebagai fasilitator bagi dampingan untuk memperoleh problematik ekonominya tanpa bantuan orang lain.

Dengan Participatory Action Research (PAR) ini bermanfaat untuk memfasilitasi dan memotivasi agar masyarakat tani mampu: 1) Mengidentifikasi kekuatan dan 
kelebihan produk singkong dengan mendeteksi optimalnya distribusi singkong (dibantu analisis teori transportasi). 2) Menemukenali model usahataani dengan konsep intensifikasi dan menyusun strategi dan metode yang tepat untuk memecahkan permasalahan ekonomi msyarakat tani. 3) Menyusun rencana aksi berdasarkan prioritas, dan keberlanjutan program melalui tahapan-tahapan hingga mencapai target yang diharapkan

Adapun strategi yang digunakan dalam melakukan action research ini adalah menggunakan metode yang dikemukakan oleh O'Brien (2001) dengan empat gambaran proses action, yaitu: Pertama, perencanaan (plan) dengan bantuan analisis SWOT untuk mengetahui kondisi riil dampingan. Kedua, tindakan (action) yang mana kami sebagai fasilitator dan dilakukan demonstrasi kecil sebagai pilot project. Ketiga, pengamatan (observe) sebagai kelanjutan (sustainable) dari analisis SWOT guna menyelesaikan problematika yang terjadi di masyarakat dampingan. Dan keempat, Refleksi (reflect).

Sebelum pada pelaksanaan PAR, metode untuk menjawab tujuan distribusi adalah dengan menggunakan teknik analisis deskriptif secara integratif (Islam), yaitu menemukan titik temu antara ilmu pengetahuan dan agama, utamanya ayat-ayat Alqur'an dan Al-Hadist yang disampaikan secara simbolik dapat dianalisis sehingga simbolik tersebut dapat diterima secara akal berdasarkan dan tidak keluar dari substansi Al-Qur'an dan Al-Hadist itu sendiri.

Berdasarkan isu-isu di atas, maka bentuk kegiatan yang akan dilakukan dalam penelitian action ini antara lain: a) Focus Group Discussion (FGD) untuk mengakomodir kebutuhan dan permasalahan dampingan. b) Diskusi (Workshop) penyusunan program kegiatan berdasarkan hasil FGD. c) Penyusunan modul usatani intensifikasi guna meminimisasi ke-efisien-an lahan pertanian d) Pelatihan yang terencana berdasarkan program kegiatan yang telah disepakati (agreement). e) Pendampingan yang berkelanjutan (sustainable). Dan f) Semua rangkaian akan dievaluasi secara terus menerus

\section{HASIL}

Hasil penelitian dilakukan pada kelompok saran sebanyak 10 orang yang masing-masing orang 'diwajibkan' menanam minimal 100 pohon singkong sehingga 
terdapat 1000 pohon dengan pemanfaatan lahan pematang (kosong) disamping tanaman utama yang diusahakan kelompok sasaran. Hal ini dilakukan atas kesepatakan (agreement) bersama sebab jika mereka tidak dibebaskan dalam menanan, maka biaya sewa tanah cukup mahal dan kemungkinan besar petani enggan dalam mengaksesnya.

Informasi terbaru tentang harga sewa tanah sekitar Rp.2-3,5 juta per tahun. jika batang setek dengan ukuran 3-4 ruas mata atau 15-20 cm dan bagian bawah dari batang stek dipotong miring dengan maksud untuk menambah, memperluas daerah perakaran dengan bentuk agak miring dengan kedalaman 8-12 cm, maka setiap hektar dapat dilakukan penanaman pophon singkong sebanyak 10.000 batang/ha atau dapat dimaksimalkan sebanyak populasi 14.500 batang/ha.

Pola tanam yang dapat diterapkan adalah sistem monokultur adalah $100 \times 50$ $\mathrm{cm}$, dapat juga dilakukan dengan sistem tumpangsari tinggal penyesuaian dengan bentuk lahan dan tanam 'pendampingnya'. Pada lahan tegalan/kering, waktu tanam yang paling baik adalah awal musim hujan atau setelah penanaman padi. Ada beberapa literatur, menyajikan bahwa jarak tanam yang umum digunakan pada pola monokultur ada beberapa alternatif yaitu : $100 \times 100 \mathrm{~cm}$ atau $100 \times 60 \mathrm{~cm}$ atau $100 \times 40$ $\mathrm{cm}$ atau $80 \times 120 \mathrm{~cm}$. Bila pola tanam dengan sistem tumpang sari bisa dengan jarak tanam $150 \times 100 \mathrm{~cm}$ atau $200 \times 150 \mathrm{~cm}$.

Meskipun idealnya pola tanaman sebagaimana dipaparkan di atas, tetapi penelitian memberikan kebebasan dalam pelaksanaan pola tanamnya sesuai dengan pengalaman masing-masing petani kelompok sasaran. Hal ini didasarkan bahwa semangat melakukan action research adalah pergerakan penanaman pohon singkong dengan pemanfaatan lahan pematang (kosong) sehingga singkong menjadikan komoditas yang dapat menambah peran pada ketahanan pangan.

Secara historis, tanaman ini sudah begitu banyak ditanam disemua lahan (pekarangan) sehingga terjadi kelebihan produksi dan harga semakin menuru. Kejadian ini berlangsung terus menerus selama bertahun-tahun yang pada akhirnya singkong masuk katagori komoditas inferior (jelek). Pada beberapa daeraifis olah singkong dengan berbagai bentuk olahan, menjadikan komoditas ini sebagai makanan pokok. 
Perkembangan selanjutnya, fenomena klasik tuntutan pangan berbasis beras dan jagung semakin tinggi menyebabkan menipisnya stok beras yang terus melaju ditambah lagi terjadi laju pertumbuhan penduduk semakin meningkat. Alternatifnya adalah komoditas singkong dan terbukti menjadikan singkong berangsur-angsur meningkat - peningkatan ini masih belum bisa dibarengi dengan produksi yang memadahi sehingga ada indikasi kekurangan bahan baku singkong. Atas dasar itulah, maka action research ini sebagai salah satu alternatif untuk 'menutupi' kekurangan tersebut. Hasil penelitian menunjukan bahwa pemanfaatan lahan pematang per orang 100 batang dari 10 orang atau 10\% komoditas singkong dapat dipenuhi dari action research ini.

Secara regional, di Jawa Timur produksi mengalamai kelebihan dari semua kabupaten - demikian juga di kabupaten Malang luas usahatani singkong yang terluas bertururt-turut adalah Kecamatan Donomulyo, Bantur, Dampit dan Tirtoyudo dengan produksi yang dihasilkan pada tahun 2001 secara berurutan sebesar 80.842 ton, 86.652 ton, 87.394 ton dan 41.003 ton. Sebagai mana pada penelitian sebelumnya menurut ukuran BPS; jika kebutuhan per kapita singkong sebesar $8 \%$ dari kebutuhan pokok, maka 33 kecamatan yang ada di wilayah Kabuapten Malang diestimasikan akan kelebihan (exes supply). Namun, apabila dilakukan simulasi dengan menaikkan kebutuhan singkong dua kalipat dari $8 \%$, maka akan terjadi kelebihan permintaan (exes demand).

Beberapa hasil temuan pasca program dilakukan melalui penelitian ini dapat dijelaskan sebagai berikut: 1) Usahatani singkong dapat memberikan keuntung ekonomi karena memberikan kontribusi yang cukup significant pada kehidupan rumah tangga petani. 2) Dengan pengalaman usahatani singkong yang awalnya sebagai usaha sampingan ternyata memberikan pemahaman yang cukup mendalam tentang karakteristik singkong, yaitu dapat menyembuhkan penyakit maag. 3) Pemanfaatan lahan pematang adalah solusi petani yang melakukan penanaman singkong yang sebelumnya menanam di lahan tegal yang sekarang beralih tegal untuk komoditas tebu. 4) Muncul rasa kesadaran bahwa pemanfaatan pematang lahan adalah menghindari dari ke-mubadzir-an (boros). 5) Usahatani singkong pada lahan pekarangan menjadikan produksi cukup baik dan bagus bagaikan lingkaran bulat 
yang mengelilingi batang singkong, tetapi pada lahan basah (sawah) tidak demikian produksi sedikit dan penampilan kurang baik. 6) Komoditas singkong memunculkan keuntungan sosial ekonomi yang cukup terasa. Aspek sosialnya adalah ada rasa 'kangen' (ketagihan). 7) Program PAR dengan penanaman pemanfaatan lahan pematang ('galengan') dapat meminimalisasi hama penyakit tikus, hal senada dikuatkan oleh kebanyakan kelompok sasaran yang menyebutkan bahwa tikus akan terhibur ('keslimuur': jawa), dan tanaman utamanya tidak akan rusak. 8) Program PAR mendorong dan memunculkan ide baru untuk melakukan usaha lainnya, seperti olah singkong yang siap saji.

Karena itulah kelompok sasaran mempunyai ide yang dikembangkan sendiri dengan melakukan ekpansi usatani singkong yang lebih banyak dan luas. Ekpansi usatani dilakukan juga oleh kelompok sasaran untuk menanam kayu (sengon basyiah) dan bibit 'loong' yaitu bibit ketela rambat disela-sela singkong dan tanaman sengon basyiah. Mereka menganggap saling menguntungkan dari aspek sosial ekonominya. Ekspansi pemanfaan lahan tidak hanya pada 'pematang' tetapi pemanfaatan lahan yang mengalami 'longsor kecil' (juogrog; jawa) karena juogrog disamping akan tertutupi tanaman singkong juga menahan erosi yang lebih besar lagi.

Relevansi hasil temuan dan Model O'Brien (2001), dapat dijelaskan bahwa; tiga hal yang harus dilalui dengan untuk merevansikan hasil temuan dengan model analisis dari O'Brien, yaitu perencanaan (plan), tindakan (action), pengamatan (observe) dan refleksi (reflect). Untuk memudahkannya dikelompokkan dalam bentuk matrik berikut:

Tabel 1:

Relevansi Hasil Temuan dan Model O’Brien

\begin{tabular}{|c|c|c|c|c|}
\hline \multirow{2}{*}{$\begin{array}{l}\text { Perencanaan } \\
\text { (plan) }\end{array}$} & \multirow[t]{2}{*}{ Tindakan (action) } & \multicolumn{2}{|c|}{ Pengamatan (observe) } & \multirow{2}{*}{$\begin{array}{l}\text { Refleksi } \\
\text { (reflect) }\end{array}$} \\
\hline & & Sebelum & Sesudah & \\
\hline \multicolumn{5}{|c|}{ KEMITRAAN YANG TERBANGU PADA SEMUA PIHAK } \\
\hline $\begin{array}{l}\text { Kelompok } \\
\text { sasaran } \\
\text { pelaku } \\
\text { produsen dan } \\
\text { peneliti }\end{array}$ & $\begin{array}{l}\text { - Kemitraan } \\
\text { hulu-hilir } \\
\text { - Kemitraan }\end{array}$ & $\begin{array}{l}\text { Usahatani } \\
\text { singkong } \\
\text { dilakukan } \\
\text { sebagai usaha } \\
\text { sampingan }\end{array}$ & $\begin{array}{l}\text { Upaya } \\
\text { dilakukan } \\
\text { dengan } \\
\text { kelompok } \\
\text { sasaran: }\end{array}$ & $\begin{array}{l}\text { Renungan: } \\
\text { - Singkong } \\
\text { adalah } \\
\text { komoditas } \\
\text { yang dekat } \\
\text { dengan }\end{array}$ \\
\hline
\end{tabular}




\begin{tabular}{|c|c|c|c|c|}
\hline $\begin{array}{l}\text { - Peneliti dan } \\
\text { pene rima } \\
\text { produksi } \\
\text { (usaha } \\
\text { gorengan } \\
\text { singkong) } \\
\text { - Sosialisasi dan } \\
\text { jajak pendapat } \\
\text { tentang 'ide' } \\
\text { inovasi } \\
\text { peneliti }\end{array}$ & $\begin{array}{l}\text { dengan } \\
\text { kesepakatan }\end{array}$ & $\begin{array}{l}\text { dan tidak ada } \\
\text { jaringan dan } \\
\text { bersifat } \\
\text { independent }\end{array}$ & $\begin{array}{l}\text { Diusahakan } \\
\text { pada lahan } \\
\text { pekarangan } \\
\text { Diperluas pada } \\
\text { lahan tegal } \\
\text { Dicoba pada } \\
\text { galengan } \\
\text { sawah }\end{array}$ & $\begin{array}{l}\text { masyarakat } \\
\text { kelompok } \\
\text { sasaran } \\
\text { - Singkong } \\
\text { adalah } \\
\text { komoditas } \\
\text { yang terdesak } \\
\text { dengan } \\
\text { tanaman tebu } \\
\text { - Singkong } \\
\text { adalah } \\
\text { komoditas } \\
\text { langka }\end{array}$ \\
\hline \multicolumn{5}{|c|}{ ADOPSI INOVASI MODEL YANG TELAH DIPERKENALKANNYA } \\
\hline $\begin{array}{l}\text { Kelompok } \\
\text { sasaran tetap } \\
\text { menjalankan } \\
\text { usahatani } \\
\text { singko ng } \\
\text { yang selama } \\
\text { ini dilakukan }\end{array}$ & \multirow{3}{*}{$\begin{array}{l}\text { - Siap jalankan } \\
\text { hasil kemitraan } \\
\text { utamanya } \\
\text { pemba gian } \\
\text { hasil 50:50 } \\
\text { - Adopsi minimal } \\
\text { 100 } \\
\text { pohon/orang } \\
\text { dan maksimal } \\
\text { 300 } \\
\text { pohon/ orang } \\
\text { tetapi beberapa } \\
\text { yang } \\
\text { melakukan } \\
\text { ekspansi usaha } \\
\text { singkong lebih } \\
\text { dari } 300 \text { pohon } \\
\text { (lihat dokumen) }\end{array}$} & \multirow{3}{*}{$\begin{array}{c}\text { Tidak } \\
\text { memperha } \\
\text { tikan jenis } \\
\text { singkong } \\
\text { karena tidak } \\
\text { memperhati } \\
\text { kan pasar }\end{array}$} & \multirow{3}{*}{$\begin{array}{l}\text { Adopsi jenis } \\
\text { singkong hijau } \\
\text { yang } \\
\text { berorientasi } \\
\text { pada pasar. }\end{array}$} & \multirow{3}{*}{$\begin{array}{l}\text { - Singkong } \\
\text { adalah } \\
\text { sebagai obat } \\
\text { untuk } \\
\text { penderita } \\
\text { lambung } \\
\text { - Singkong } \\
\text { komoditas } \\
\text { yang 'nga- } \\
\text { ngen-ni' } \\
\text { - Singkong } \\
\text { sebagai } \\
\text { komoditas } \\
\text { yang dapat } \\
\text { meminimi } \\
\text { sasi hama } \\
\text { tikus karena } \\
\text { jika ditanam } \\
\text { di lahan } \\
\text { sawah (padi) } \\
\text { - hama tikus } \\
\text { 'terlupakan' } \\
\text { pada padi }\end{array}$} \\
\hline $\begin{array}{l}\text { - 'ide' usahatani } \\
\text { dia dopsi \& } \\
\text { akan di } \\
\text { bandingkan } \\
\text { dg hasil } \\
\text { singkong yg } \\
\text { telah dilakuka } \\
\text { nnya }\end{array}$ & & & & \\
\hline $\begin{array}{l}\text { - 'ide' } \\
\text { pemasaran yg } \\
\text { dikoordinasi } \\
\text { kan dg mitra } \\
\text { dise pakati } \\
\text { nya }\end{array}$ & & & & \\
\hline \multicolumn{5}{|c|}{ KEMANDIRIAN KELOMPOK SASARAN PASCA PROGRAM SELESAI } \\
\hline $\begin{array}{l}\text { - Mereka akan } \\
\text { tetap } \\
\text { melakukan } \\
\text { program } \\
\text { meski } \\
\text { program } \\
\text { selesai }\end{array}$ & \multirow{2}{*}{$\begin{array}{l}\text { Kemandirian } \\
\text { usa ha tani lebih } \\
\text { dari } 300 \text { pohon }\end{array}$} & \multirow{2}{*}{$\begin{array}{l}\text { Belum } \\
\text { terpola }\end{array}$} & \multirow{2}{*}{$\begin{array}{l}\text { Terpola dengan } \\
\text { memperhatika } \\
\mathrm{n}\end{array}$} & \multirow{2}{*}{\begin{tabular}{|l} 
- Singkong \\
dapat \\
dipakai \\
sebagai \\
tambahan \\
dever sifikasi \\
penjualan \\
makan \\
utama (nasi).
\end{tabular}} \\
\hline $\begin{array}{l}\text { - Model adalah } \\
\text { biasa }\end{array}$ & & & & \\
\hline
\end{tabular}




\begin{tabular}{|c|c|c|c|}
\hline $\begin{array}{l}\text { dilakukan nya } \\
\text { kelompok } \\
\text { sasaran }\end{array}$ & $\begin{array}{c}\text { kare na tertarik } \\
\text { dan sa dar } \\
\text { bahwa singko }\end{array}$ & kemitraannya & $\begin{array}{l}\text { - Seingkong } \\
\text { dapat } \\
\text { perluas pada }\end{array}$ \\
\hline $\begin{array}{l}\text { Usahatani } \\
\text { bukan hal } \\
\text { yang baru } \\
\end{array}$ & $\begin{array}{l}\text { ng memang per } \\
\text { lu bahkan } \\
\text { sampai }\end{array}$ & & $\begin{array}{l}\text { lahan tegal } \\
\text { yang tidak } \\
\text { 'mengganng }\end{array}$ \\
\hline $\begin{array}{l}\text { Hasil } \\
\text { usahatani } \\
\text { untuk } \\
\text { kelanjutan } \\
\text { kelengkapan } \\
\text { usa ha } \\
\text { sampingan } \\
\text { (warung) } \\
\end{array}$ & $\begin{array}{c}\text { diusahakan } \\
\text { secara profesio } \\
\text { nal (gulud-an) }\end{array}$ & & $\begin{array}{l}\text { u 'tanaman } \\
\text { utama nya. } \\
\text { - Singkong } \\
\text { komoditas } \\
\text { yang inferior } \\
\text { ('jelek') } \\
\text { tetapi } \\
\text { disadari }\end{array}$ \\
\hline $\begin{array}{l}\text { - Hasil } \\
\text { usahatani } \\
\text { singkong } \\
\text { untuk } \\
\text { menopang } \\
\text { kanakan } \\
\text { sampi ngan } \\
\text { selain beras } \\
\end{array}$ & & & $\begin{array}{l}\text { bahwa } \\
\text { singkong } \\
\text { juga } \\
\text { mendatang } \\
\text { kan } \\
\text { tambahan } \\
\text { income } \\
\text { rumah }\end{array}$ \\
\hline $\begin{array}{l}\text { - Makanan sing } \\
\text { kong tidak } \\
\text { akan ditinggal } \\
\text { meski } \\
\text { program } \\
\text { selesai }\end{array}$ & & & $\begin{array}{l}\text { tangga (house } \\
\text { houlde). } \\
\text { - Singkong } \\
\text { adalah } \\
\text { komoditas } \\
\text { peng ganti } \\
\text { (substitusi) } \\
\text { beras yang } \\
\text { dekat. }\end{array}$ \\
\hline \multicolumn{4}{|l|}{ Analisis SWOT } \\
\hline \multicolumn{4}{|c|}{ KEKURANGAN, angpan singkong tidak menguntung kan } \\
\hline \multicolumn{4}{|c|}{ KELEBIHAN; usahatani singkong tidak asing bagi mereka } \\
\hline \multicolumn{4}{|c|}{ PELUANG, dapat di tumbuhkembang kan lebih luas } \\
\hline \multicolumn{4}{|c|}{ ANCAMAN, kompetsisi lahan untuk tebu } \\
\hline
\end{tabular}

\section{KESIMPULAN}

Berdasarkan hasil pembahasan di muka, maka dapat ditarik kesimpulan bahwa optimal distribusi singkong 2011 di Kabupaten Malang belum mencapai optimal karena keseimbangan belum tercapai (unbalance) artinya masih terjadi 
kelebihan dan kekurangan permintaan dan kelebihan produksi singkong. Di kabupaten Malang luas usahatani singkong yang terluas bertururt-turut adalah Kecamatan Donomulyo, Bantur, Dampit dan Tirtoyudo dengan produksi yang dihasilkan pada tahun 2001 secara berurutan sebesar 80.842 ton, 86.652 ton, 87.394 ton dan 41.003 ton. Sebagai mana pada penelitian sebelumnya menurut ukuran BPS; jika kebutuhan per kapita singkong sebesar 8 \% dari kebutuhan pokok, maka 33 kecamatan yang ada di wilayah Kabuapten Malang diestimasikan akan kelebihan (exes supply). Namun, apabila dilakukan simulasi dengan menaikkan kebutuhan singkong dua kalipat dari 8 \%, maka akan terjadi kelebihan permintaan (exes demand).

Pemberdayaan rumah tangga tani sebagai jamaah Masjid Nurul Huda melalui pemanfaatan lahan kosong dan/pekarangan guna menghindari kemubadiran lahan. Hasilnya menunjukkan bahwa usahatani singkong dengan program PAR dapat memunculkan keuntungan sosial, ekonomi, kesehatan dan keuntungan budaya menanam singkong pada lahan 'kosong' sehingga rasa kesadaran bahwa pemanfaatan pematang lahan adalah menghindari dari kemubadhiran (keborosan). Aspek sosialnya adalah ada rasa 'kangen' (ketagihan). Pada pemanfaatan lahan pematang ('galengan') dapat meminimalisasi hama penyakit tikus, hal senada dikuatkan oleh kebanyakan kelompok sasaran yang menyebutkan bahwa tikus akan terhibur ('keslimuur': jawa), dan tanaman utamanya tidak akan rusak. Ekspansi pemanfaalah tidak hanya pada 'pematang' tetapi pemanfaatan lahan yang mengalami 'longsor kecil' (juogrog; jawa) karena juogrog disamping akan tertutupi tanaman singkong juga menahan erosi yang lebih besar lagi.

\section{Saran}

Dalam rangka menumbuhkembangkan ketahanan pangan melalui singkong, maka budaya penanaman singkong perlu dilakukan sebagaimana pada program PAR ini dilakukan. Dasar adopsi inovasi ini tentunya adalah kesepakatan (agreement) dengan masyarakat dan kebutuhan (needs) mereka.

\section{DAFTAR RUJUKAN}

Biro Pusat Statistik. 2010. Kabupaten Malang Dalam Angka. Malang. 
Jurusan Ilmu-Ilmu Sosial Ekonomi, 1997. Mimbar Sosek. Journal of Agricultural and Resource Social-Economics. Volume 10, Number 3, August, 1997. ISSN : 02158434.

Masyhuri. 1996. Pola Alokasi Tenaga Kerja Keluarga Dalam Menunjang Perekonomian Rumah Tangga pada Daerah Pengembangan Kawasan Industri. DIKTI. No.116/P21PT/DPPM/LITMUD/1996.

Masyhuri, 1998. Studi Kelayakan Mendirikan Cold Storage (CS) dan Milk Treatmen (MT) pada Beberapa Koperasi Unit Desa (KUD) Produsen Susu Sapi Perah di Kab. Malang. DIKTI. No.130/P21PT/DPPM/98 LITMUD/V/1998.

Masyhuri, 1998. Pemberdayaan Masyarakat Pedesaan pada Industrialisasi Pedesaan sebagai Upaya Menanggulangi Kemiskinan dalam Rangka Menghadapi Era Globalisasi. Penelitian Hibah Bersaing, DIKTI. No.75/P21PT/PHB/VII-1/V/1999. (tahun I).

Masyhuri. 1999. Pemberdayaan Masyarakat Pedesaan pada Industrialisasi Pedesaan sebagai Upaya Menanggulangi Kemiskinan dalam Rangka Menghadapi Era Globalisasi. Penelitian Hibah Bersaing, DIKTI. No.044/P21PT/HB/VII2/1999. (tahun I dan II).

Masyhuri. 2000. Usaha Pembentukan "koperasi Tani" pada Masyarakat Pedesaan Guna Menuju Masyarakat Mandiri sebagai Sarana untuk Pemberdayaan Usahatani PALAGUNG (padi-palawija-jagung). Penelitian Dosen Muda, DIKTI. No.089/P21PT/DM/VI/2000.

Masyhuri. 2002. Analisis Perencanaan Sumberdaya Pertanian Yang Optimal. Disertasi S-3. Surabaya: Program Studi Ilmu Ekonomi Pembangunan PPS UNAIR Surabaya.

Masyhuri. 2003. Studi Potensi Wilayah Poncokusumo Untuk AGRO ECO TURISM Dari Aspek Prasarana dan Produk Unggulan Wilayah. BALITBANG Kab. Malang. Nomor SPK/SPMK: 074/282/ KEP/421.203/2003

Masyhuri. 2008. Optimalisasi Distribusi Singkong yang Berimbang (balance) Guna Mendukung Ketahanan Pangan. PHB: DP2M Ditjen Dikti Depdiknas, No Kontrak: 231/SP2H/PP/DP2M/III/2008. Tgl. 6 Maret 2008 (tahunI) 
Masyhuri. 2010. Optimalisasi Distribusi Singkong yang Berimbang (balance) Guna Mendukung Ketahanan Pangan. Dibiayai DP2M Ditjen Dikti Depdiknas. No Kontrak: 110/SP/2H/PP/DP2M/ III/2010.

Masyhuri. 2011. Optimalisasi Distribusi Singkong yang Berimbang (balance) Guna Mendukung Ketahanan Pangan. Dibiayai DP2M Ditjen Dikti Depdiknas. No Kontrak: 0080/SP2H/PP/K7/KL/IV/2011

Masyhuri (2012).Optimalisasi Distribusi Singkong yang Berimbang (balance) Guna Mendukung Ketahanan Pangan. Dibiayai DP2M Ditjen Dikti Depdiknas. No Kontrak: 0032/SP2H/PP/K7/KL/II/2012. 9 Pebruari 2012.

Mufida, 2010. Program participatory action research (PAR) Pemberdayaan mutu remaja miskin perkotaan Di kelurahan kasin kec. Klojen Kota Malang. Lemlit UIN Malang: Laporan Penelitian.

Mufida, 2012. Ensiklopedia Mukjizat Ilmiah Al-Quran dan Hadis. Jakarta: PT.Lentera Abadi.

http:/ / satriamadangkara.com/harga-sewa-tanah-untuk-budidaya-singkong-atauketela-pohon/\#ixzz2E5Obi2UX 